\title{
Relationship of arsenic accumulation with irrigation practices and crop type in agriculture soils of Bengal Delta, India
}

\author{
S. H. Farooq ${ }^{1}$ D. Chandrasekharam ${ }^{2,3} \cdot$ W. Dhanachandra ${ }^{2} \cdot \mathrm{K} \mathrm{Ram}^{4}$
}

Received: 11 February 2017 / Accepted: 31 January 2019 / Published online: 5 June 2019

(c) The Author(s) 2019

\begin{abstract}
The present study investigates the current state and distribution of As in the upper soil horizons (i.e. rhizospheric zone, 0-15 cm) of two different agricultural fields: (1) paddy-cultivating agricultural field that was irrigated with groundwater containing $137 \mu \mathrm{g} / \mathrm{L}$ of As and (2) wheat-cultivating agricultural field that was irrigated with groundwater having $67.3 \mu \mathrm{g} / \mathrm{L}$ of arsenic. Results clearly indicate different levels of As accumulation in the upper soil horizons of both profiles. In paddy field, although significantly higher quantity of As-contaminated groundwater was used for irrigation, still lesser than expected As concentration in soils was found [average As concentration $16.0 \mathrm{mg} / \mathrm{kg}$ (measured) vs. $29.0 \mathrm{mg} / \mathrm{kg}$ (calculated)]. The imbalance between higher influx of As and its relatively lower accumulation in soils indicates the existence of a mechanism (organic carbon mechanism, elaborated in the main text) that is responsible for continuous removal of As, and ultimately prevents the expected shoot-up of As in the paddy soils. On the other hand, although lesser quantity of less contaminated groundwater is used in wheat field, still wheat field soils show relatively higher As accumulation [average As concentration $22.5 \mathrm{mg} / \mathrm{kg}$ (measured) vs. $12.2 \mathrm{mg} / \mathrm{kg}$ (calculated)]. Such accumulation of As happens when there is continuous influx of As through irrigation water and/or other sources, and an effective (natural) mechanism to remove As from the wheat soil is absent. Adoption of distinct harvesting methods is responsible for existence of different mechanisms in paddy and wheat fields, which ultimately cause the differential accumulation of As in paddy and wheat soils.
\end{abstract}

Keywords Arsenic in agriculture soils · Paddy cultivation - Wheat cultivation · Soil organic matter $\cdot$ Arsenic mass balancing

This article is part of the Topical Collection "Water and Energy" guest edited by Enrico Drioli.

Electronic supplementary material The online version of this article (https://doi.org/10.1007/s13201-019-0904-1) contains supplementary material, which is available to authorized users.

S. H. Farooq

hilalfarooq@iitbbs.ac.in

1 School of Earth, Ocean and Climate Sciences, IIT Bhubaneswar, Bhubaneswar 751007, India

2 Department of Earth Sciences, IIT Bombay, Powai, Mumbai 400076, India

3 Department of Civil Engineering, Indian Institute of Technology Hyderabad, Hyderabad 502285, India

4 Institute of Environment and Sustainable Development, Banaras Hindu University, Varanasi 221005, India

\section{Introduction}

Arsenic contamination in the groundwater is probably the worst case of mass poisoning in the history of mankind and poses a severe threat to the worldwide groundwater resources (Chatterjee et al. 1995). Many countries in the world are facing problems of As contamination in the groundwater. However, this problem is most severe in many Southeast Asian countries including India, Bangladesh, Cambodia, Vietnam, etc. (Ahamed et al. 2006; Berg et al. 2007; Bhattacharya et al. 1997; Charlet and Polya 2006; Fendorf et al. 2010; Polya et al. 2005). Elevated As concentrations in the groundwater have been reported from many Indian states, namely West Bengal, Bihar, Uttar Pradesh, Assam, Jharkhand, Chhattisgarh and Madhya Pradesh (Acharyya et al. 2005; Ahamed et al. 2006; Bhattacharjee et al. 2005; Chakraborti et al. 1999, 2003; Chandrasekharam et al. 2001; Das et al. 1996; Paul and Kar 2004). However, because of the extent and severity 
of the As contamination in the groundwater of Bengal Delta Plain (BDP), it has drawn a lot of attention from the scientific community. Over 50 million people in BDP are routinely exposed to As poisoning through drinking of contaminated groundwater, and around $45 \%$ of the total population living in As-affected areas of West Bengal is severely affected (Fewtrell et al. 2005; Smith et al. 2000). Different aspects of As contamination of groundwater have been investigated by various researchers around the globe (Berg et al. 2007; Charlet et al. 2007; Guo et al. 2007; McArthur et al. 2001; Mukherjee et al. 2008; Nath et al. 2008; Norra et al. 2012; Smedley and Kinniburgh 2002; Stüben et al. 2003; van Geen et al. 2006), but still several gaps exist in scientific knowledge.

In BDP, As-contaminated groundwater is extensively used for irrigation purposes. Arsenic supplied through the contaminated irrigation water accumulates itself in soil and in different parts of plant body. Correlations between As concentrations in irrigation water and affected soils are documented (Dittmar et al. 2007; Neidhardt et al. 2012; Norra et al. 2005; Stüben et al. 2007; van Geen et al. 2006). However, a comparative study of As accumulation and distribution in agricultural fields/soils cultivating different crop types (e.g. paddy vs. wheat) and irrigated with As-contaminated water has not yet been investigated. Such comparisons are important as different crops not only require different quantities of water to be pumped into the agricultural fields but also follow different cultivation practices which may control As accumulation or mobilization in these soils. In this paper, we present a comparative study of As accumulation in two different agricultural fields (i.e. a paddy- and a wheatcultivating field).

\section{Materials and methods}

\section{Sampling sites and collection of samples}

Two agricultural fields with different crop types (paddy and wheat) but irrigated with As-contaminated groundwater were selected. These fields are located in Kaliachak block I $\left(24^{\circ} 51^{\prime}-24^{\circ} 56^{\prime} \mathrm{N} ; 88^{\circ} 01^{\prime}-88^{\circ} 06^{\prime} \mathrm{E}\right)$ of Malda district in West Bengal, India (L-1 for paddy and L-2 for wheat; Fig. 1) and are around $1.8 \mathrm{~km}$ away from each other. To select suitable agricultural fields that are irrigated by As-contaminated groundwater, groundwater samples were collected from 29 different tube wells in the Kaliachak block I as shown in Fig. 1. In agricultural field L-1, different varieties of rice were cultivated throughout the year and the groundwater used for irrigation contained $137 \mu \mathrm{g} / \mathrm{L}$ of arsenic. On the other hand, wheat was the main cultivating crop in field L-2 and the groundwater irrigating this field contained $67.3 \mu \mathrm{g} / \mathrm{L}$ of arsenic.

Groundwater samples were collected in polyethylene (PE) bottles and were filtered in the field using $0.45-\mu \mathrm{m}$ cellulose nitrate filter. In order to avoid any precipitation, filtered water samples were acidified by adding $5 \mathrm{~mL}$ of ultrapure
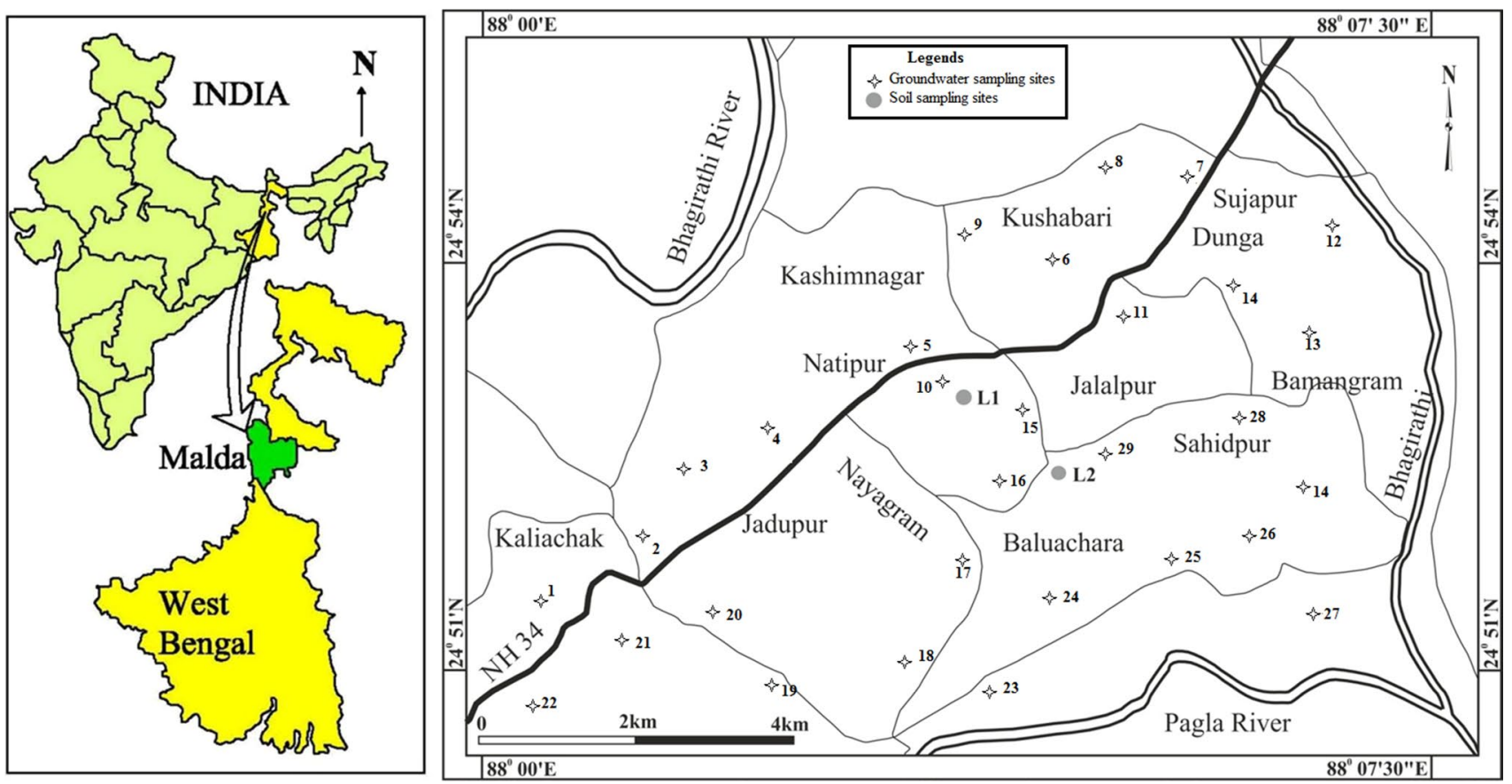

Fig. 1 Location of groundwater and soil sampling sites (L-1: paddy and L-2: wheat) in the Kaliachak block I of Malda district in West Bengal, India selected in this study 
$\mathrm{HNO}_{3}$ (concentration $14 \mathrm{M}$ ) per litre of groundwater and stored at a low temperature $\left(4^{\circ} \mathrm{C}\right)$ until further analysis. To collect soil samples, separate trenches of $100 \mathrm{~cm}(\mathrm{~L}) \times 75 \mathrm{~cm}$ (W) $\times 110 \mathrm{~cm}$ (D) were dug in the centre of both agricultural fields and two opposite corners ( $\mathrm{N}$ and $\mathrm{S}$ ) of each trench were sampled following composite sampling technique. Soil samples at every $5 \mathrm{~cm}$ of vertical interval were collected in the first $30 \mathrm{~cm}$ depth, and then samples were collected at every $10 \mathrm{~cm}$ till the end of the profile (i.e. $110 \mathrm{~cm}$ ). A total of 28 soil samples (14 samples at each corner) were collected to cover the entire soil profile of paddy field (L-1). Approximately, $150 \mathrm{~g}$ of soil was collected from each sampling point and stored immediately into zip-lock plastic bags. The other trench located in wheat field (at L-2) was also sampled in the same manner. In the laboratory, soil samples were freezedried and stored in the nitrogen atmosphere in refrigerator until further analysis. Hereafter, the soil profiles collected from the paddy and wheat fields will simply be referred as paddy soil profile and wheat soil profile, respectively. Removal of As from agriculture fields through various crop products is one of the important pathways. To calculate the amount of As leaving agriculture fields via crop products, three plant samples from each field were collected. Care has been taken not to lose any part of plant while uprooting. Excessive soil along the roots was washed away immediately. After drying, the plant samples were preserved in zip-lock plastic bags. In the laboratory plant samples were washed thoroughly with double distilled water and dried in oven at $105{ }^{\circ} \mathrm{C}$ for $24 \mathrm{~h}$. The plant samples were separated into grains, leaf and stem by a ceramic scissors. Each part was cut into small pieces and ground into powder. Powered samples were stored in plastic containers.

\section{Chemical analysis of water, soil and plant samples}

Concentration of As and other elements in the groundwater samples was measured by high-resolution ICP-MS (Axiom, Thermo/VG Elemental, UK). In case of soil samples, a subset of samples was powdered and used for energy-dispersive $\mathrm{X}$-ray fluorescence (ED-XRF) and X-ray diffraction (XRD) analysis. Constituent minerals in soil samples were identified by means of X-ray diffraction analysis (Kristalloflex D500, Siemens) as described in (Norra et al. 2006). Semi-quantification of minerals in soil samples was done by comparing the spectra of samples with the calibration curves of known mineral composition (Snyder and Bish 1989). The fractions of quartz, feldspar, dolomite, kaolinite and mica were determined on the basis of related reflected X-ray intensities. The fractions of mineral phases plus organic matter were summed up, and the fraction of clay minerals comprising minerals such as smectites, vermiculites and chlorites was determined by taking the difference from total sample (i.e. $100 \%)$. The clay mineral fraction also includes oxides and amorphous constituents that may present in small quantities, and their concentrations were below detection limits (bdl).

Elemental composition of soils was determined by EDXRF (Spectra 5000, Atomica) using standard analytical techniques as described in Kramar (1997) and (1999). The detection limits for $\mathrm{As}, \mathrm{Cu}$ and $\mathrm{Zn}$ were 1.8, 4.6, $3.3 \mathrm{mg} /$ $\mathrm{kg}$, respectively, and those for $\mathrm{Fe}_{2} \mathrm{O}_{3}$ and $\mathrm{MnO}$ were $0.03 \%$ and $0.005 \%$, respectively (Norra et al. 2006). Accuracy was checked by analysing certified reference material (CRMs) such as GXR-2, Soil-5, GXR-5, SL-1 and SCO-1. To control the quality, these CRMs have been repeatedly analysed. In general, precision was better than $5 \%$ and accuracy was better than $10 \%$ for all the analysis.

Total carbon (TC) content in soil samples was measured by a Carbon-Sulphur-Analyser (CSA 5003, Leybold Heraeus, Germany), while inorganic carbon (IC) content was determined by Carbon-Water-Analyser (CWA 5003, Leybold Heraeus, Germany). Total organic carbon $\left(C_{\text {org }}\right)$ content in the soils was calculated by subtracting inorganic carbon from the total carbon content (i.e. $C_{\text {org }}=C_{\text {tot }}-C_{\text {inorg }}$ ).

To determine the concentration of As and other elements, total digestion of powdered plant samples was done in a microwave digestion system (MW system, Start 1500, MLS GmbH) in a stepwise manner. A complete digestion was achieved, and the solution was analysed for As through high-resolution ICP-MS (Axiom, Thermo/VG Elemental, UK). All the analytical work presented in this paper was carried out at the Institute of Mineralogy and Geochemistry, Karlsruhe Institute of Technology_Karlsruhe, Germany.

\section{Results}

\section{Analysis of groundwater and plant samples}

Groundwater samples, collected from 29 different tube wells, were analysed for As and other elements. The detailed result of these samples is not discussed here, as it is beyond the scope of this paper (for detailed results, see Appendix 1, Sheet\#I of Electronic Supplementary Material). The concentration of As in groundwater samples (i.e. irrigation wells) ranged between 2 and $850 \mu \mathrm{g} / \mathrm{L}$. The two irrigation wells having As concentration of $137 \mu \mathrm{g} / \mathrm{L}$ and $67.3 \mu \mathrm{g} / \mathrm{L}$ were selected. These wells supply water for irrigating paddy (L-1) and wheat fields (L-2), respectively. To calculate the As budget, it is important to determine the quantity of As leaving the agriculture field along with various crop products. In this regard, As concentrations in different parts of plant were measured. Arsenic concentration in grains, leaf and stem of paddy and wheat plant shows a consistently increasing trend with the highest As concentrations found in stem. However, the transfer coefficient of As between stem, leaf and grain is different for paddy plant than that of the 
wheat plant. In paddy plant, $0.35 \mathrm{mg} / \mathrm{kg}$ of As was found in rice grain, while $1.71 \mathrm{mg} / \mathrm{kg}$ and $2.26 \mathrm{mg} / \mathrm{kg}$ has been measured in leaf and stem, respectively. In wheat plant, As concentrations of $0.01 \mathrm{mg} / \mathrm{kg}, 2.97 \mathrm{mg} / \mathrm{kg}$ and $0.69 \mathrm{mg} / \mathrm{kg}$ have been measured in grain, leaf and stem, respectively. The highest As concentration $(40.3 \mathrm{mg} / \mathrm{kg}$ and $4.82 \mathrm{mg} / \mathrm{kg}$ for paddy and wheat plants, respectively) was found in the roots. Harvesting of paddy and wheat crop does not involve uprooting of plants; therefore, the As associated with roots does not leave the agriculture field. For this reason, the As concentration in the roots is not considered while calculating the As budget for the agriculture fields. A Microsoft excel sheet has been developed to calculate the inflow and outflow of As (As budget) into the different agriculture fields through irrigation water and agriculture products, respectively (Appendix 2, Sheet \#I of Electronic Supplementary Material). This excel sheet can widely be used by anyone working on mass balancing of an element in an agriculture field.

\section{Elemental composition along soil profiles}

In this study, the entire soil profile of paddy and wheat field has been divided into two horizons: the upper horizon $(0-15 \mathrm{~cm})$ and the lower horizon $(15-110 \mathrm{~cm})$ because of the fact that roots of most "Leguminous group" of plants remain within top $15 \mathrm{~cm}$ of soil profile. Furthermore, average depth between two subsequent samples has been assumed to represent average composition of soil sample in particular depth interval (i.e. average concentration at $2.5 \mathrm{~cm}$ depth represents concentration between 0 and $5 \mathrm{~cm}$ depth). Arsenic concentration in paddy soil profile (i.e. both horizons combined) ranged between 12.0 and $18.0 \mathrm{mg} / \mathrm{kg}$, with an average As concentration of $15.2 \mathrm{mg} / \mathrm{kg}$ (Table 1, Fig. 2). The topmost paddy soil layer $(0-5 \mathrm{~cm})$ has $15 \mathrm{mg} / \mathrm{kg}$ of As concentration which increased gradually with depth and reached a value of $17 \mathrm{mg} / \mathrm{kg}$ at an average depth of $12.5 \mathrm{~cm}$. After this depth, arsenic concentration decreased, and between 30 and $40 \mathrm{~cm}$ the lowest As concentration $(12 \mathrm{mg} / \mathrm{kg})$ has been registered. Arsenic concentration did not show much variation between 15 and $80 \mathrm{~cm}$ depth and range between 12.0 and $14.5 \mathrm{mg} /$

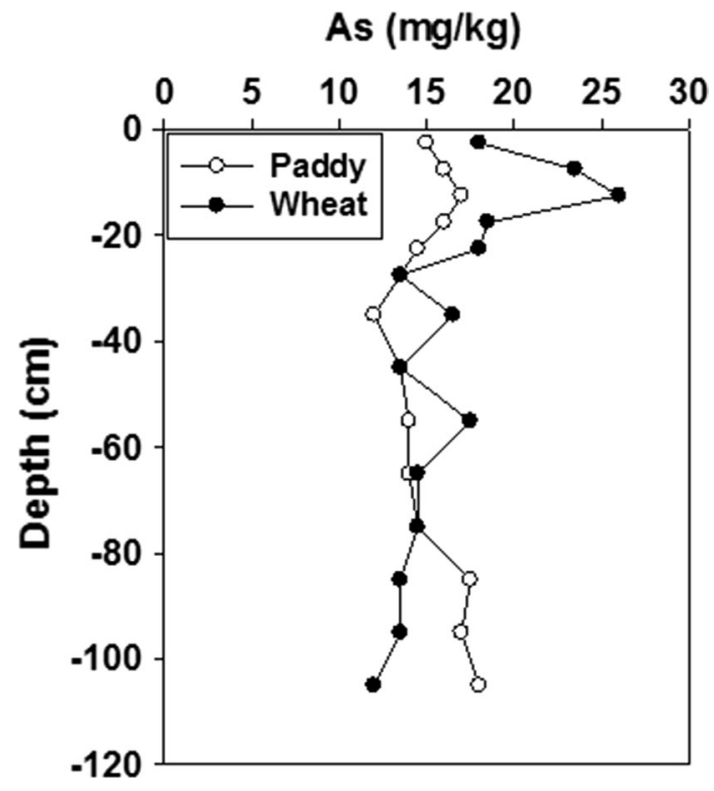

Fig. 2 Variation in As concentrations with depth along the paddy and wheat soil profile

$\mathrm{kg}$. However, again elevated values of As concentration were found between 80 and $110 \mathrm{~cm}$ and the highest As concentration $(18 \mathrm{mg} / \mathrm{kg})$ was recorded at a depth of $110 \mathrm{~cm}$.

Arsenic concentration along the wheat soil profile (i.e. both horizons combined) varied between 12 and $26 \mathrm{mg} / \mathrm{kg}$ (average: $16.6 \mathrm{mg} / \mathrm{kg}$ ). However, in the upper soil horizon $(0-15 \mathrm{~cm})$, wheat soils show As concentration of $22.5 \mathrm{mg} / \mathrm{kg}$ which is considerably higher than that of paddy soils where $16.0 \mathrm{mg} / \mathrm{kg}$ of As has been registered. The lower soil horizon $(15-110 \mathrm{~cm})$ of both fields does not show any variation in average As concentrations, and $15 \mathrm{mg} / \mathrm{kg}$ of As has been registered. In general, As concentrations were relatively higher in wheat soil profile, compared to those in paddy soils, up to a depth of $55 \mathrm{~cm}$. Similar to paddy soil profile, wheat profile also shows a gradual increase in As concentrations in the upper horizon and maximum As concentration of $26 \mathrm{mg} / \mathrm{kg}$ was registered at the depth of $15 \mathrm{~cm}$ (Fig. 2). However, the lowest As concentration $(12 \mathrm{mg} / \mathrm{kg}$ ) was found at the deepest
Table 1 Statistical summary of concentrations of various elements along paddy and wheat soil profile

\begin{tabular}{lllllllll}
\hline Depth $(\mathrm{cm})$ & Field Type & $\mathrm{K}^{2} \mathrm{O}^{*}$ & $\mathrm{CaO}^{*}$ & $\mathrm{Fe}_{2} \mathrm{O}_{3}{ }^{*}$ & $\mathrm{Cu}^{\#}$ & $\mathrm{Zn}^{\#}$ & $\mathrm{As}^{\#}$ & $\mathrm{~Pb}^{\#}$ \\
\hline $0-15$ & Paddy & 3.2 & 4.5 & 9.0 & 56.0 & 106.5 & 16.0 & 22.2 \\
& Wheat & 2.8 & 2.1 & 8.7 & 55.3 & 100.5 & 22.5 & 21.7 \\
\multirow{3}{*}{$15-110$} & Paddy & 2.9 & 3.2 & 9.6 & 61.3 & 107.4 & 15.0 & 22.7 \\
& Wheat & 3.0 & 5.2 & 7.4 & 46.7 & 85.5 & 15.1 & 18.1 \\
$0-110$ & Paddy & 3.0 & 3.4 & 9.5 & 60.2 & 107.2 & 15.2 & 22.6 \\
& Wheat & 2.9 & 4.5 & 7.7 & 48.5 & 88.7 & 16.6 & 18.9 \\
\hline
\end{tabular}

$* \mathrm{~K}_{2} \mathrm{O}, \mathrm{CaO}$, and $\mathrm{Fe}_{2} \mathrm{O}_{3}$ are in percentage (w/w)

${ }^{\#} \mathrm{Cu}, \mathrm{Zn}, \mathrm{As}, \mathrm{Pb}$ are in $\mathrm{mg} / \mathrm{kg}$ 


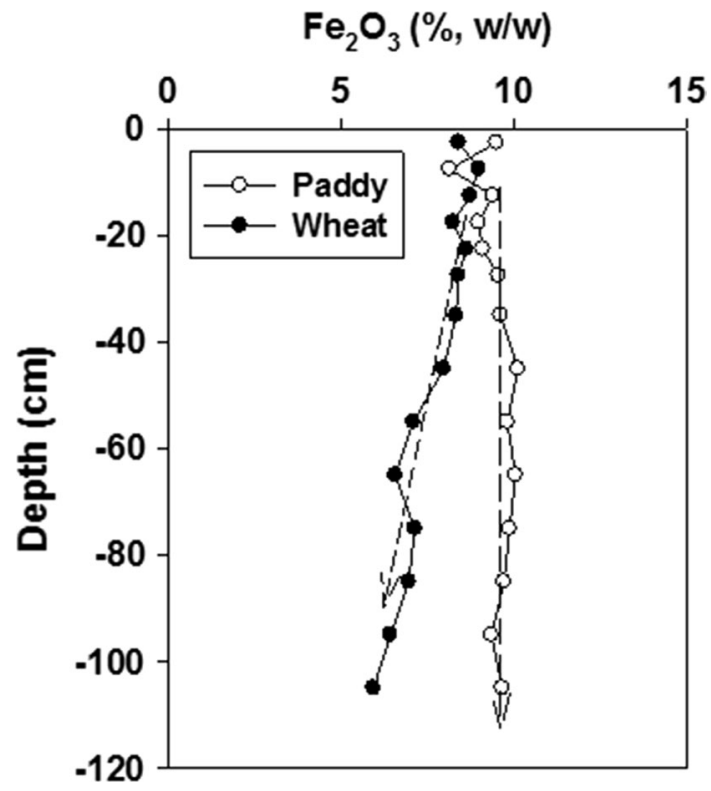

Fig. 3 Variation in $\mathrm{Fe}$ concentrations (as $\mathrm{Fe}_{2} \mathrm{O}_{3}$ ) with depth along paddy and wheat soil profile. The dashed arrows indicate the trend of Fe concentration with depth

level (i.e. at $110 \mathrm{~cm}$ depth). This is in sharp contrast to that for paddy soil samples. The detailed elemental composition of individual soil sample of both profiles is given in Appendix 1, Sheet \#II of Electronic Supplementary Material.

Unlike As, iron ( $\mathrm{Fe}$ as $\mathrm{Fe}_{2} \mathrm{O}_{3}$ ) in the paddy soil profile showed a very limited variation in concentration along the depth of profile (Fig. 3). Iron concentrations in paddy soil profile ranged between 8.1 and $10.1 \%$, with the highest $\mathrm{Fe}$ concentration recorded in samples collected between $40-50 \mathrm{~cm}$ and $60-70 \mathrm{~cm}$ depths. In case of wheat soil profile, Fe concentrations varied between 5.9 and $9.0 \%$ with an average iron concentration of $7.7 \%$. In contrast to the paddy soil profile, Fe concentration in wheat soil profile showed a significant and gradual decrease with depth and the lowest $\mathrm{Fe}$ concentration (5.9\%) was registered at a depth of $110 \mathrm{~cm}$ (Fig. 3). However, average iron concentration in paddy soil profile (average: $9.5 \%$ ) was relatively higher than that for wheat soil (average: $7.7 \%$ ).

Manganese ( $\mathrm{Mn}$ as $\mathrm{MnO}$ ) concentrations were very low throughout the paddy profile and ranged between 0.07 and $0.12 \%$, with an average value of $0.09 \%$. In the same profile, the concentration of $\mathrm{Cu}$ and $\mathrm{Zn}$ varied between 50.0 and $65.0 \mathrm{mg} / \mathrm{kg}$ (average $60.2 \mathrm{mg} / \mathrm{kg}$ ) and $96.5-113 \mathrm{mg} /$ $\mathrm{kg}$ (average $107 \mathrm{mg} / \mathrm{kg}$ ), respectively (Fig. 4a, b). Similar to paddy soil profile, Mn concentrations also did not show much variation in wheat soil profile, and concentration varied between 0.07 and $0.12 \%$, with an average value of $0.09 \%$. The concentration of $\mathrm{Cu}$ and $\mathrm{Zn}$ for wheat profile ranged between $38.5-57.5 \mathrm{mg} / \mathrm{kg}$ and $67.5-106 \mathrm{mg} / \mathrm{kg}$, respectively (Fig. 4a, b).

\section{Mineralogy along soil profiles}

Semi-quantification of minerals present in two soil profiles $(0-110 \mathrm{~cm})$ showed a marked difference (Fig. 5a, b). Paddy soil profile is dominated by clay minerals (average 42.4\%), and at a depth between 70 and $80 \mathrm{~cm}$ clay mineral makes up to a maximum of $57 \%$ of total mineral present (Fig. 5a,

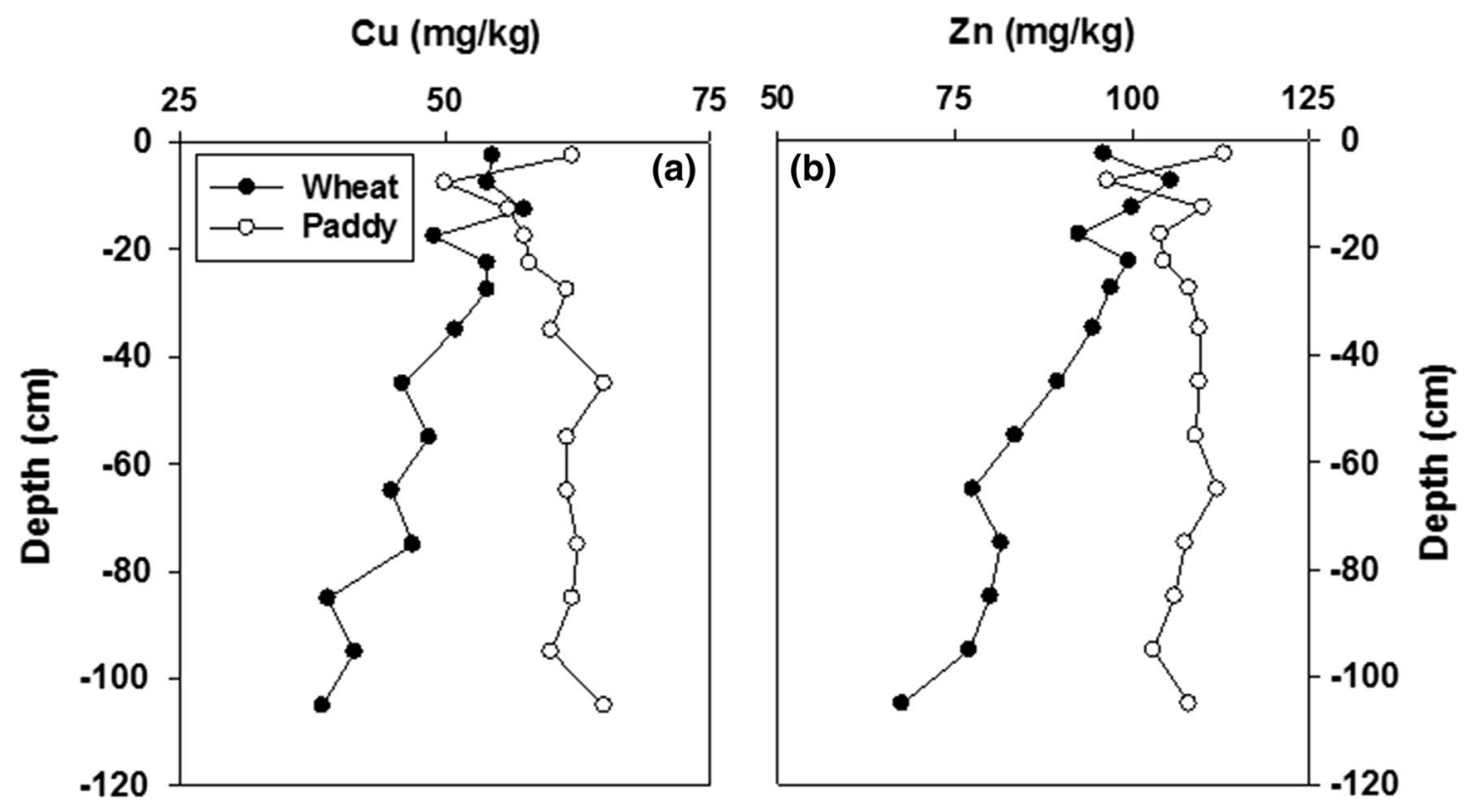

Fig. 4 Variation in concentrations of $\mathrm{Cu}$ and $\mathrm{Zn}$ (redox sensitive trace elements) with depth along paddy and wheat soil profile 
Fig. 5 Variation of mineral composition of soils with depth along paddy and wheat profile

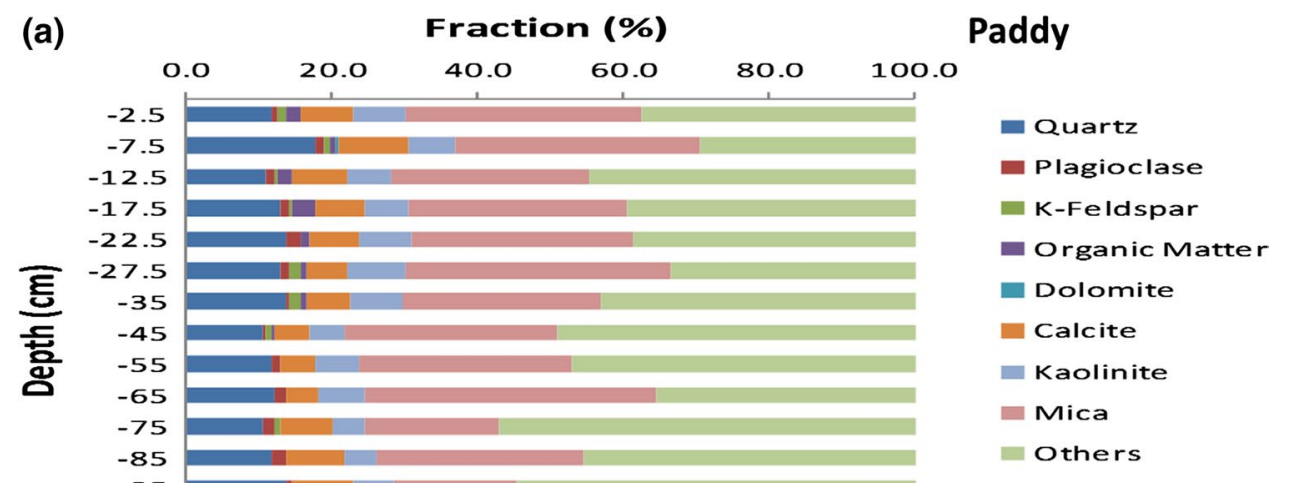

Fraction (\%)

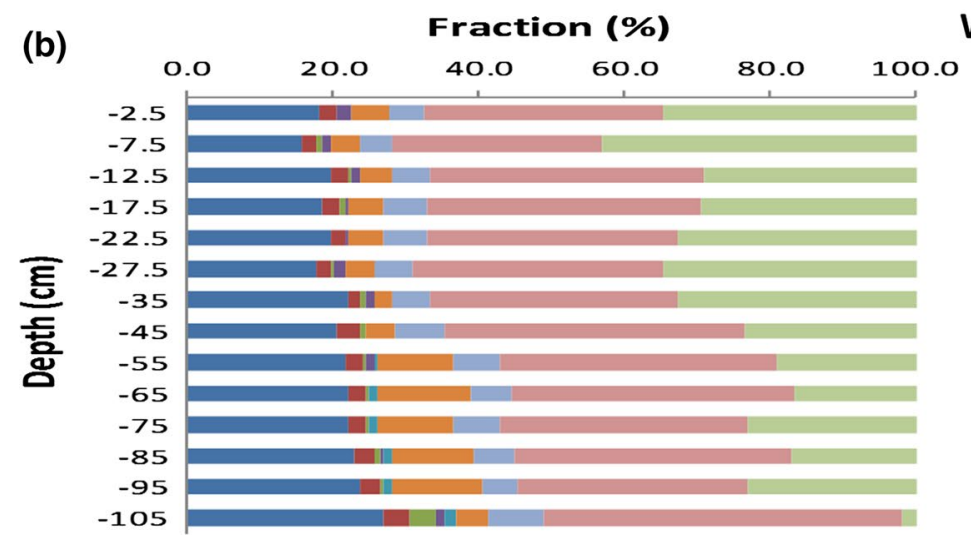

\section{Wheat}

Table 2 Statistical summary of abundances of minerals in paddy and wheat soil profile

\begin{tabular}{|c|c|c|c|c|c|c|c|c|c|}
\hline \multirow[t]{2}{*}{ Depth $(\mathrm{cm})$} & \multirow[t]{2}{*}{ Field Type } & \multicolumn{8}{|l|}{ Minerals } \\
\hline & & Quartz (\%) & $\begin{array}{l}\text { Pla- } \\
\text { gioclase } \\
(\%)\end{array}$ & K-feldspar (\%) & Dolomite (\%) & Calcite (\%) & Kaolinite (\%) & Mica (\%) & $\begin{array}{l}\text { Phyllosilicates*/ } \\
\text { clay minerals }(\%)\end{array}$ \\
\hline \multirow[t]{2}{*}{$0-15$} & Paddy & 13.3 & 1.2 & 0.7 & 0.2 & 8.2 & 6.5 & 31.2 & 37.2 \\
\hline & Wheat & 17.7 & 2.3 & 0.5 & $<0.1$ & 4.5 & 5.0 & 33.2 & 35.5 \\
\hline \multirow[t]{2}{*}{$15-110$} & Paddy & 12.3 & 1.3 & 0.5 & $<0.1$ & 6.5 & 6.0 & 29.0 & 43.8 \\
\hline & Wheat & 21.5 & 2.5 & 0.9 & 0.5 & 7.5 & 6.0 & 37.4 & 23.0 \\
\hline \multirow[t]{2}{*}{$0-110$} & Paddy & 12.5 & 1.3 & 0.5 & $<0.1$ & 6.9 & 6.1 & 29.5 & 42.4 \\
\hline & Wheat & 20.7 & 2.5 & 0.8 & 0.4 & 6.9 & 5.8 & 36.5 & 25.7 \\
\hline
\end{tabular}

*includes other minerals below detection limit

Table 2). In contrast, average concentration of clay minerals in wheat profile was only $25.7 \%$, which is significantly lower (i.e. $\approx 1.5$ times) than that in the paddy profile. However, it is interesting to note that the upper soil horizons $(0-15 \mathrm{~cm})$ of both agriculture field show comparable concentration of clay minerals $(37.2 \%$ and $35.5 \%$ for paddy and wheat soils, respectively) which vary widely in the lower soil horizon (43.8\% and $23 \%$ for paddy and wheat soils, respectively). In entire soil profiles $(0-110 \mathrm{~cm})$ clay mineral are quite high in paddy soils $(42.4 \%)$ than the wheat soils $(25.7 \%)$. The average concentration of quartz in wheat profile was $\approx 1.5$ times higher $(20.7 \%)$ than that in the paddy profile (only $12.5 \%$ ). Fractional contribution of other minerals such as mica and plagioclase in paddy soil profile was relatively lower (average concentration of $29.5 \%$ and $1.3 \%$, respectively), as compared to those in wheat profile $(36.5 \%$ and $2.5 \%$, respectively) (Fig. 5b, Table 2).

Organic matter (OM) content of paddy profile ranged between 0.2 and $2.8 \%$ (average $1.0 \%$ ), whereas it varied between 0.3 and $2.2 \%$ (average $0.9 \%$ ) in wheat profile. Organic matter concentration was estimated as 1.7 times the concentration of total organic carbon (TOC) in soil samples 


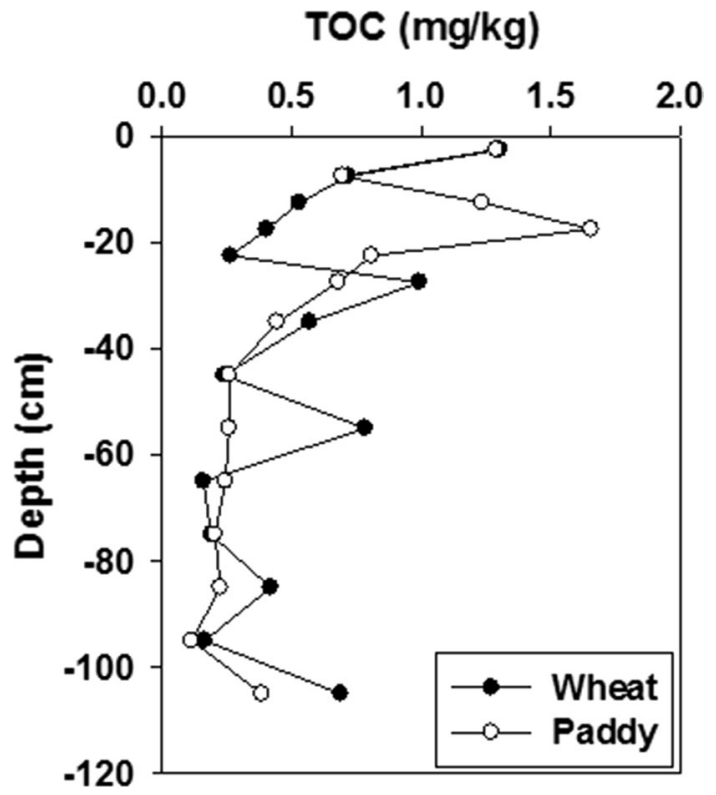

Fig. 6 Variation of TOC concentrations with depth along paddy and wheat soil profile

(i.e. $\mathrm{OM}=1.7 \times \mathrm{TOC}$ ). In case of paddy profile, maximum OM concentration was found at a depth of $15-20 \mathrm{~cm}$ (Fig. 6). Organic matter content showed a gradual decrease between 20 and $100 \mathrm{~cm}$, and the lowest concentration $0.2 \%$ was detected at a depth of 90-100 $\mathrm{cm}$ in paddy profile (Fig. 6 and Appendix 1, Sheet \#III of Electronic Supplementary Material). However, higher organic matter content $(0.7 \%$ for wheat and $0.4 \%$ for paddy) was registered at the depth of $100-110 \mathrm{~cm}$. In wheat profile, organic matter does not show either a continuously increasing or decreasing trend with the depth (Fig. 6). However, organic matter concentrations in paddy and wheat soil profile exhibit opposite trend between 5 and $25 \mathrm{~cm}$ depths (Fig. 6).

\section{Discussion}

Average As concentration of $16.0 \mathrm{mg} / \mathrm{kg}$ and $22.5 \mathrm{mg} / \mathrm{kg}$ was measured in the top $15 \mathrm{~cm}$ of soils of paddy and wheat profiles, respectively. Arsenic concentrations are significantly higher than the background concentration $(\approx 10 \mathrm{mg} /$ $\mathrm{kg}$; Norra et al. 2005) in top soils irrespective of the field type (i.e. paddy or wheat field). The extent of As accumulation and distribution in agricultural soil depends primarily on the As concentration in irrigation water and irrigation intensity (Ahmad et al. 2006; Patel et al. 2005; Stüben et al. 2007; van Geen et al. 2006). However, there are several other factors such as soil mineralogy, clay and organic matter content which also play a crucial role. In subsequent sections, possible reasons and mechanisms for As accumulation and distribution in paddy and wheat agricultural soils have been discussed.

Both paddy and wheat fields were irrigated with As-contaminated water of different concentrations. Arsenic concentration in groundwater used for paddy field irrigation (As concentration: $137 \mu \mathrm{g} / \mathrm{L}$ ) is roughly two times higher than that used for wheat field (As concentration $67.3 \mu \mathrm{g} / \mathrm{L}$ ). Paddy fields need flooded conditions during the cultivation, which requires larger amount of groundwater to be pumped in the fields. For example, Jehangir et al. (2007) have shown that $1458 \mathrm{~mm}$ of average gross inflow of water takes place in paddy fields compared to only $357 \mathrm{~mm}$ of water inflow in wheat fields. These values may vary slightly depending on local climatic factors (such as rainfall and evaporation) and irrigational and agricultural practices followed during the cultivation. However, in general, paddy fields require $\approx 4$ times higher quantities of water than wheat fields, and thus, paddy fields are supplied with many fold higher As content through contaminated irrigation water. Earlier studies have demonstrated that irrigation with As-rich groundwater introduces $\approx 1360$ tons of As into paddy soils of Bangladesh each year (Ali et al. 2003; Linda et al. 2012; Meharg and Rahman 2002). A major portion of As brought along with contaminated irrigation water initially accumulates in top agricultural soils, while the remaining fraction accumulates itself in different parts of plant body (Neidhardt et al. 2012; Norra et al. 2005; Stüben et al. 2007).

Considering the concentration of As in irrigation water and quantity of water used in paddy field, it is expected that As concentration in top $15 \mathrm{~cm}$ of paddy soils should be at least eightfold higher than those in wheat field soils (i.e. 2 times As concentration in irrigation water and 4 times higher water supply).

Further, our As budget calculation shows that irrigation water supplies $\approx 200 \mathrm{mg} / \mathrm{m}^{2} /$ year of As to paddy field of which $\approx 0.5 \mathrm{mg} / \mathrm{m}^{2} /$ year is removed from the agricultural field through various crop products (i.e. rice grain, stem, etc., Appendix 2, Sheet \#I of Electronic Supplementary Material). The distribution of remaining As in upper soil horizon will lead to $\approx 1 \mathrm{mg} / \mathrm{kg} /$ year increase in As concentration. Paddy is cultivated in this field since last more than 20 years; thus, $29.0 \mathrm{mg} / \mathrm{kg}$ of As (including background concentration $10 \mathrm{mg} / \mathrm{kg}$ of As) must be present in the upper soil horizon (Appendix 2, Sheet \#I of Electronic Supplementary Material). Similarly, in wheat field $\approx 24 \mathrm{mg} / \mathrm{m}^{2} /$ year of As comes with irrigation water and $\approx 0.5 \mathrm{mg} / \mathrm{m}^{2} /$ year is removed along with the crop products. The distribution of remaining As in upper soil horizon may cause an increase in $0.11 \mathrm{mg} / \mathrm{kg} /$ year, and over a period of 20 years, $12.2 \mathrm{mg} /$ $\mathrm{kg}$ (including the background As conc.) would have been accumulated in upper soils.

However, average As concentration in top $15 \mathrm{~cm}$ of paddy soil is $16.0 \mathrm{mg} / \mathrm{kg}$ which is $\approx 30 \%$ lower than that in wheat 
field $(22.5 \mathrm{mg} / \mathrm{kg})$ and $\approx 45 \%$ lower than the calculated concentration $(29.0 \mathrm{mg} / \mathrm{kg})$. This indicates the existence of a mechanism that either prevents accumulation of As in top soils or continuously removes the As accumulated in paddy fields. Arsenic concentrations in BDP soil generally decrease with depth (Dittmar et al. 2007); however, no such trend has been observed in the paddy soil profile and As concentrations remained stable or slightly increased with depth in our study (Fig. 2). Such a trend further supports the existence of an As removal (remobilization) mechanism in the upper soil horizon and subsequent transfer to the lower horizon. The quantity of clay minerals present in the soil plays a crucial role in As accumulation, as it not only provides binding sites for As but also enhances ion-exchange capacity (OnaNguema et al. 2005). The presence of relatively high quantity of clay minerals in top $15 \mathrm{~cm}$ of both profiles $(37.2 \%$ paddy and $35.5 \%$ wheat) may have provided greater chance for As adsorption and thus, leading to high concentration of As in top soils. However, this cannot explain the observed differences in As concentration in the top soils of two different agricultural fields as clay content in both fields is nearly the same (Fig. 2). Furthermore, iron plaque formation takes place on the roots of paddy plant during cultivation (i.e. in the rhizospheric zone; typically between 0 and $15 \mathrm{~cm}$ depth), which adsorbs As and causes an increase in As concentration in top soils (Caetano and Vale 2002; Kirk et al. 2004; Norra et al. 2005; Otte et al. 1995). However, it is interesting to note that Fe does not show any enrichment in the rhizospheric zone and is rather slightly lower between 5 and $10 \mathrm{~cm}$ depth, and thereafter, it is almost uniform throughout the soil profile (Fig. 3). On the other hand, As concentration in top soils of wheat profile is significantly higher than that in paddy soil profile. This may be due to the absence or less effectiveness of As transfer mechanism from upper to lower soil horizons. This suggests that As accumulation mechanisms in paddy and wheat soils are significantly different and As in paddy soils have undergone some remobilization processes after the crop is harvested.

Leaching and transportation of As from top soils to the underlying soils represent a possible pathway of As removal from the top soils (Farooq et al. 2010; Polizzotto et al. 2006). Dittmar et al. (2007) have suggested that As accumulated in top few centimetres, during the monsoon flooding, diffuses into the floodwater, and thus, As concentration in top soils remains lower than the expected values. However, during the monsoon season, fields in the study area are filled with water but flooding (i.e. overflow) does not occur. This limits the possibility of washing away of As with floodwater.

The relative enrichment of redox sensitive elements (such as $\mathrm{Fe}$ in their respective mineral phases) in the lower paddy horizon $(9.6 \%$ between 15 and $110 \mathrm{~cm})$ further supports that the leaching and transportation is the dominant process (compared to diffusion and washing) for removal of As and other elements from the top paddy soils $(9.0 \%$ between 0 and $15 \mathrm{~cm})$. It is well documented that under the reducing conditions $\mathrm{Fe}^{+3}$ coverts into $\mathrm{Fe}^{+2}$ and easily gets mobilized. In paddy fields, reducing condition develops primarily due to decay of organic matter and further strengthens by the water cover (water logged conditions) that prevents the exchange of gasses from the atmosphere. The distribution of nonredox sensitive trace elements such as $\mathrm{Cu}$ and $\mathrm{Zn}$ reflects the depth distribution of clay mineral content. $\mathrm{Cu}$ and $\mathrm{Zn}$ are positively charged, whereas clay mineral surfaces are negatively charged at the given $\mathrm{pH}$ values between 7 and 8 in both soils (as obtained in this study).

The difference in As accumulation in paddy and wheat fields can be understood by observing the differences in the agricultural practices adopted for cultivating the respective crops. In wheat field, when crop is harvested, it is cut from the bottom of the stem and the leftover is burnt in the field. However, harvested crop is cut from the middle of the stem in paddy cultivation and the remaining half of the stem (lower portion) and roots are ploughed back for the next cultivation. This way significant quantity of organic matter remains available in paddy field. The organic matter starts to decompose during the next cultivation (i.e. monsoon season) when the fields are filled with water. Studies have also shown that standing water in paddy fields contains high TOC content, ranging between 56 and $128 \mathrm{mg} / \mathrm{L}$ (Farooq et al. 2010). The decomposition of organic matter induces reducing condition in the paddy field and helps in remobilization of arsenic (Mladenov et al. 2010; Lawson et al. 2016). In addition, decomposition of organic matter produces weak organic acids which reacts with the mineral surfaces and modifies their sorption behaviour (Farooq et al. 2012, 2010; Senesi et al. 1994). Negatively charged ions from dissolved organic acids increase desorption of As from binding sites through electrostatic effects (Bauer and Blodau 2006). This leads to leaching of As from upper soil horizon to the lower horizon and thus keeps the As profile steady and uniform in case of paddy soils (Fig. 2).

In the absence of such cultivation practices (i.e. ploughing back the remaining parts of previous crop) and the existence of non-flooded conditions in the wheat field, only weak reducing condition develops. Under such conditions, only a small fraction of As remobilizes and the rest remains accumulated in the upper horizon of wheat field soils. Thus, despite of lower As concentration in irrigation water and lesser water usage, As concentrations are found to be higher in upper horizon of wheat soil profile. In addition, limited transfer of As from upper to lower horizon causes a decreasing trend in As concentration with depth. The findings of the present study emphasize that the presence of higher surficial organic matter content and its decomposition plays an important role in distribution and remobilization of As in paddy soils. In contrast, lesser availability of organic matter 
in wheat field limits remobilization of As from wheat soils. These results further corroborate earlier observations of As mobilization from the soils with the inflow of young carbon (Harvey et al. 2002). Thus, the present study highlights the existence of different mechanisms that operate in paddy and wheat fields and controls the distribution of As in soils.

Globally in most of the As-affected areas, a closely knitted web of rivers and streams exists. The water in these surface water bodies is free from As; thus, the use of surface water for irrigation purposes should be encouraged (Chandrasekharam 2007). Such a practice on the one hand will stop supply of As to the agriculture soil and on the other hand will clean up the soil by redistributing the accumulated arsenic. In places where it is difficult to fetch water from river, local rain-fed ponds can be utilized for irrigation purposes.

\section{Conclusion}

We present a comparative study of the distribution of As in paddy- and wheat-cultivating soils irrigated with groundwater having different concentrations of arsenic. The results suggest that As distribution mechanism is different for paddy and wheat soils. The As content present in irrigation water serves as an important source of As to the pedosphere and initially accumulates in top soil horizon $(0-15 \mathrm{~cm})$. The decomposition of surficial organic matter and subsequent production of weak organic acids are important factors in controlling the distribution of As in paddy and wheat soils. In paddy fields, reducing conditions generated by decomposition of organic matter triggers redox induced As mobilization and organic acids produced prevents the As readsorption. This mechanism causes transfer of a major fraction of As accumulated in the top soils to the deeper horizons. Due to the limited availability of organic matter in wheat field, only weak reduction conditions are generated, and thus, major fraction of As remains accumulated in top soil. The study highlights that As accumulation and distribution in agricultural soils not only depend on As concentration in irrigation water and quantity of water supplied but also on agricultural practices and crop type.

Acknowledgements SHF gratefully acknowledges SERB for funding though young scientist project (DST/SERB No.: SR/FTP/ES-43/2011). WD acknowledges the support from German Academic Exchange Program (DAAD) through fellowship. Indian Institute of Technology Bombay (India) and Institute of Mineralogy and Geochemistry (IMG)-Karlsruhe (Germany) are thanked for providing laboratory facility to carry out this research work. Furthermore, we thank Dr. Kaynat Tabassum her valuable comments and endless support in improving the manuscript.
Open Access This article is distributed under the terms of the Creative Commons Attribution 4.0 International License (http://creativeco mmons.org/licenses/by/4.0/), which permits unrestricted use, distribution, and reproduction in any medium, provided you give appropriate credit to the original author(s) and the source, provide a link to the Creative Commons license, and indicate if changes were made.

\section{References}

Acharyya SK, Shah BA, Ashyiya ID, Pandey Y (2005) Arsenic contamination in groundwater from parts of Ambagarh-Chowki block, Chhattisgarh, India: source and release mechanism. Environ Geol 49(1):148-158

Ahamed S, Kumar Sengupta M, Mukherjee A, Amir Hossain M, Das B, Nayak B, Pal A, Chandra Mukherjee S, Pati S, Nath Dutta R, Chatterjee G, Srivastava R, Chakraborti D (2006) Arsenic groundwater contamination and its health effects in the state of Uttar Pradesh (UP) in upper and middle Ganga plain, India: a severe danger. Sci Total Environ 370(2-3):310-322

Ahmad KM, Huq SMI, Naidu R (2006) Extent and severity of arsenic poisoning in Bangladesh. In: Naidu R, Smith E, Owens G, Bhattacharya P, Nadebaum P (eds) Managing arsenic in the environment: from soil to human health. CSIRO Publishing, Melbourne, pp 525-540

Ali MA, Badruzzaman ABM, Jalil MA, Hossain MD, Ahmed MF, Masud AA, Kamruzzaman M, Rahman MA (2003) Fate of arsenic extracted with groundwater. In: Ahmed MF (ed) Fate of Arsenic in the Environment. ITN International Training Network, Dhaka, pp 7-20

Bauer M, Blodau C (2006) Mobilization of arsenic by dissolved organic matter from iron oxides, soils and sediments. Sci Total Environ 354(2-3):179-190. https://doi.org/10.1016/j.scito tenv.2005.01.027

Berg M, Stengel C, Trang PTK, Hung Viet P, Sampson ML, Leng M, Samreth S, Fredericks D (2007) Magnitude of arsenic pollution in the Mekong and Red River Deltas-Cambodia and Vietnam. Sci Total Environ 372(2-3):413-425

Bhattacharjee S, Chakravarty S, Maity S, Dureja V, Gupta KK (2005) Metal contents in the groundwater of Sahebgunj district, Jharkhand, India, with special reference to arsenic. Chemosphere 58(9):1203-1217. https://doi.org/10.1016/j.chemospher e.2004.09.055

Bhattacharya P, Chatterjee D, Jacks G (1997) Occurrence of arseniccontaminated groundwater in alluvial aquifers from delta plains, eastern India: options for safe drinking water supply. Int J Water Resour Dev 13(1):79-92

Caetano M, Vale C (2002) Retention of arsenic and phosphorus in iron-rich concretions of Tagus salt marshes. Mar Chem 79(3-4):261-271

Chakraborti D, Biswas BK, Roy Chowdhury T, Basu GK, Mandal BK, Chowdhury UK, Mukherjee SC, Gupta JP, Chowdhury SR, Rathore KC (1999) Arsenic groundwater contamination and sufferings of people in Rajnandangao, Madhya Pradesh, India. Curr Sci 77(4):502-504

Chakraborti D, Mukherjee SC, Pati S, Sengupta MK, Rahman MM, Chowdhury UK, Lodh D, Chanda CR, Chakraborti AK, Basu GK (2003) Arsenic groundwater contamination in Middle Ganga Plain, Bihar, India: a future danger? Environ Health Perspect 111(9):1194-1201

Chandrasekharam D (2007) Pathway of arsenic from water to food, West Bengal, India. In: Aswathanarayana U (ed) Food and Water Security Food and Water Security. Taylor \& Francis Group, London, p 315

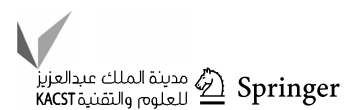


Chandrasekharam D, Karmakar J, Berner Z, Stuben D (2001) Arsenic contamination in groundwater, Murshidabad district, West Bengal. Proc Water-Rock Interact 1(2):1051-1054

Charlet L, Polya DA (2006) Arsenic in shallow, reducing groundwaters in Southern Asia: an environmental health disaster. Elements 2(2):91-96

Charlet L, Chakraborty S, Appelo CAJ, Roman-Ross G, Nath B, Ansari AA, Lanson M, Chatterjee D, Mallik SB (2007) Chemodynamics of an arsenic hotspot in a West Bengal aquifer: a field and reactive transport modeling study. Appl Geochem 22(7):1273-1292. https ://doi.org/10.1016/j.apgeochem.2006.12.022

Chatterjee A, Das D, Mandal B (1995) Arsenic in groundwater of sixdistricts of West Bengal: the biggest arsenic calamity in the world. Part 1. Arsenic species in drinking water and urine of affected people. Analyst 120:640-650

Das D, Samanta G, Mandal B, Roy Chowdhury T, Chanda C, Chowdhury P, Basu G, Chakraborti D (1996) Arsenic in groundwater in six districts of West Bengal, India. Environ Geochem Health 18(1):5-15. https://doi.org/10.1007/bf01757214

Dittmar J, Voegelin A, Roberts LC, Hug SJ, Saha GC, Ali MA, Badruzzaman ABM, Kretzschmar R (2007) Spatial Distribution and Temporal Variability of Arsenic in Irrigated Rice Fields in Bangladesh. 2. Paddy Soil. Environ Sci Technol 41(17):5967-5972. https://doi. org/10.1021/es0702972

Farooq SH, Chandrasekharam D, Berner Z, Norra S, Stüben D (2010) Influence of traditional agricultural practices on mobilization of arsenic from sediments to groundwater in Bengal delta. Water Res 44(19):5575-5588

Farooq SH, Chandrasekharam D, Abbt-Braun G, Berner Z, Norra S, Stueben D (2012) Dissolved organic carbon from the traditional jute processing technique and its potential influence on arsenic enrichment in the Bengal Delta. Appl Geochem 27(1):292-303. https:// doi.org/10.1016/j.apgeochem.2011.09.006

Fendorf S, Michael HA, van Geen A (2010) Spatial and temporal variations of groundwater arsenic in south and southeast Asia. Science 328(5982):1123-1127. https://doi.org/10.1126/science.1172974

Fewtrell L, Fuge R, Kay D (2005) An estimation of the global burden of disease due to skin lesions caused by arsenic in drinking water. $\mathrm{J}$ Water Health 3(2):101-107

Guo H, Stüben D, Berner Z (2007) Adsorption of arsenic(III) and $\operatorname{arsenic}(\mathrm{V})$ from groundwater using natural siderite as the adsorbent. J Colloid Interface Sci 315(1):47-53. https://doi.org/10.1016/j. jcis.2007.06.035

Harvey CF, Swartz CH, Badruzzaman ABM, Keon-Blute N, Yu W, Ali MA, Jay J, Beckie R, Niedan V, Brabander D, Oates PM, Ashfaque KN, Islam S, Hemond HF, Ahmed MF (2002) Arsenic mobility and groundwater extraction in Bangladesh. Science 298(5598):1602-1606

Jehangir WA, Masih I, Ahmed S, Gill MA, Ahmad M, Mann RA, Chaudhary MR, Turral H (2007) Sustaining crop water productivity in rice-wheat systems of South Asia: a case study from Punjab Pakistan. IWMI Working Paper 115. International Water Management Institute, Colombo, Sri Lanka, 460 pp

Kirk MF, Holm TR, Park J, Jin Q, Sanford RA, Fouke BW, Bethke CM (2004) Bacterial sulfate reduction limits natural arsenic contamination in groundwater. Geology 32(11):953-956

Kramar U (1997) Advances in energy-dispersive X-ray fluorescence. J Geochem Explor 58(1):73-80. https://doi.org/10.1016/S0375 -6742(96)00053-2

Kramar U (1999) X-Ray fluorescence spectrometers. In: Lindon JC, Tranter GE, Holmes JL (eds) Encyclopaedia of spectroscopy and spectrometry. Academia Press, San Diego, pp 2467-2477

Lawson M, Polya DA, Boyce AJ, Bryant C, Ballentine CJ (2016) Tracing organic matter composition and distribution and its role on arsenic release in shallow Cambodian groundwaters. Geochim Cosmochim Acta 178:160-177
Linda CR, Stephan JH, Jessica D, Andreas V, Ruben K, Bernhard W, Ganesh CS, Borhan MB (2012) Arsenic contamination of paddy fields through groundwater irrigation in Bangladesh: risks for rice production and mitigation perspectives. In: Kawaguchi M, Misaki K, Sato H, Yokokawa T, Itai T, Nguyen TM, Ono J, Tanabe S (eds) Interdisciplinary studies on environmental chemistry - environmental pollution and ecotoxicology. Tokyo, TERRAPUB, pp 109-115

McArthur JM, Ravenscroft P, Safiulla S, Thirlwall MF (2001) Arsenic in groundwater: testing pollution mechanisms for sedimentary aquifers in Bangladesh. Water Resour Res 37(1):109-117

Meharg AA, Rahman MM (2002) Arsenic contamination of Bangladesh paddy field soils: implications for rice contribution to arsenic consumption. Environ Sci Technol 37(2):229-234. https://doi. org/10.1021/es0259842

Mladenov N, Zheng Y, Miller MP, Nemergut DR, Legg T, Simone B, Hageman C, Rahman MM, Ahmed KM, McKnight DM (2010) Dissolved organic matter sources and consequences for iron and arsenic mobilization in Bangladesh aquifers. Environ Sci Technol 44(1):123-128. https://doi.org/10.1021/es901472g

Mukherjee A, von Brömssen M, Scanlon BR, Bhattacharya P, Fryar AE, Hasan MA, Ahmed KM, Chatterjee D, Jacks G, Sracek O (2008) Hydrogeochemical comparison and effects of overlapping redox zones on groundwater arsenic near the Western (Bhagirathi subbasin, India) and Eastern (Meghna sub-basin, Bangladesh) margins of the Bengal Basin. J Contam Hydrol 99(1-4):31-48. https://doi. org/10.1016/j.jconhyd.2007.10.005

Nath B, Berner Z, Chatterjee D, Mallik SB, Stüben D (2008) Mobility of arsenic in West Bengal aquifers conducting low and high groundwater arsenic. Part II: comparative geochemical profile and leaching study. Appl Geochem 23(5):996-1011

Neidhardt H, Norra S, Tang X, Guo H, Stüben D (2012) Impact of irrigation with high arsenic burdened groundwater on the soil-plant system: results from a case study in the Inner Mongolia, China. Environ Pollut 163:8-13. https://doi.org/10.1016/j.envpol.2011.12.033

Norra S, Berner ZA, Agarwala P, Wagner F, Chandrasekharam D, Stüben D (2005) Impact of irrigation with As rich groundwater on soil and crops: a geochemical case study in West Bengal Delta Plain, India. Appl Geochem 20(10):1890-1906

Norra S, Lanka-Panditha M, Kramar U, Stüben D (2006) Mineralogical and geochemical patterns of urban surface soils, the example of Pforzheim, Germany. Appl Geochem 21(12):2064-2081. https://doi. org/10.1016/j.apgeochem.2006.06.014

Norra C, Ngoc DTM, Trang PTK, Lan VTM, Viet PH, Norra S, Kunert HJ (2012) Mental health burden and neuropsychiatric deficits of chronic arsenic exposure: first results of the Vietnamese field study. In: Understanding the geological and medical interface of arsenic, As 2012 - 4th International Congress: Arsenic in the Environment, pp. $168-170$

Ona-Nguema G, Morin G, Juillot F, Calas G, Brown GE (2005) EXAFS analysis of arsenite adsorption onto two-line ferrihydrite, hematite, goethite, and lepidocrocite. Environ Sci Technol 39(23):9147-9155. https://doi.org/10.1021/es050889p

Otte ML, Kearns CC, Doyle MO (1995) Accumulation of arsenic and zinc in the rhizosphere of wetland plants. Bull Environ Contam Toxicol 55(1):154-161

Patel KS, Shrivas K, Brandt R, Jakubowski N, Corns W, Hoffmann P (2005) Arsenic contamination in water, soil, sediment and rice of central India. Environ Geochem Health 27(2):131-145. https://doi. org/10.1007/s10653-005-0120-9

Paul AB, Kar D (2004) Ground water arsenic in Assam: a report from Brahmaputra and Barak valley. Environ Ecol 22:588-589

Polizzotto ML, Harvey CF, Li G, Badruzzman B, Ali A, Newville M, Sutton S, Fendorf S (2006) Solid-phases and desorption processes of arsenic within Bangladesh sediments. Chem Geol 228(1-3):97-111. https://doi.org/10.1016/j.chemgeo.2005.11.026 
Polya DA, Gault AG, Diebe N, Feldman P, Rosenboom JW, Gilligan E, Fredericks D, Milton AH, Sampson M, Rowland HAL, Lythgoe PR, Jones JC, Middleton C, Cooke DA (2005) Arsenic hazard in shallow Cambodian groundwaters. Mineral Mag 69(5):807-823

Senesi N, Brunetti G, La Cava P, Miano TM (1994) Adsorption of alachlor by humic acids from sewage sludge and amended and nonamended soils. Soil Sci 157(3):176-184

Smedley PL, Kinniburgh DG (2002) A review of the source, behaviour and distribution of arsenic in natural waters. Appl Geochem 17(5):517-568

Smith AH, Lingas EO, Rahman M (2000) Contamination of drinkingwater by arsenic in Bangladesh: a public health emergency. Bull World Health Organ 78(9):1093-1103

Snyder RL, Bish DL (1989) Quantitative analysis. Mod Powder Diffr 20:101-144

Stüben D, Berner Z, Chandrasekharam D, Karmakar J (2003) Arsenic enrichment in groundwater of West Bengal, India: geochemical evidence for mobilization of As under reducing conditions. Appl Geochem 18(9):1417-1434
Stüben D, Norra S, Berner Z, Kramar U, Kiczka M, Agarwala P, Chandrasekharam D, Rout $R$ (2007) Arsenic mobilisation in rice paddy soils irrigated with As-contaminated water: a synopsis of case studies from West-Bengal. In: Bullen TD, Wang Y (eds) India. Taylor and Francis, London, pp 1507-1511

van Geen A, Zheng Y, Cheng Z, He Y, Dhar RK, Garnier JM, Rose J, Seddique A, Hoque MA, Ahmed KM (2006) Impact of irrigating rice paddies with groundwater containing arsenic in Bangladesh. Sci Total Environ 367(2-3):769-777. https://doi.org/10.1016/j.scito tenv.2006.01.030

Publisher's Note Springer Nature remains neutral with regard to jurisdictional claims in published maps and institutional affiliations. 